\title{
WPLYW PROCESU ZMIAN POLITYCZNYCH W PAŃSTWACH ARABSKICH NA POLITYKE ZAGRANICZNĄ TURCJI PO 2010 ROKU
}

Proces zmian w państwach arabskich, którego początek wyznaczyły protesty w Tunezji na przełomie 2010 i 2011 roku, stanowił zaskoczenie nie tylko dla szeroko definiowanej społeczności międzynarodowej, ale także dla najważniejszych graczy w regionach Bliskiego Wschodu oraz Afryki Północnej. Do tej grupy państw z pewnością zaliczyć można Iran, Arabię Saudyjską oraz Turcję. Nowa sytuacja społeczno-polityczna w regionie stała się szczególnie interesująca z punktu widzenia tej ostatniej, zwłaszcza biorąc pod uwagę historyczny zasięg Imperium Osmańskiego. Choć imperium było państwem wielonarodowym, jego historia naznaczona była w dużym stopniu przez rywalizację pomiędzy Turkami a Arabami ${ }^{1}$. Po blisko stu latach od rozpadu Imperium wzajemna niechęć wyraźnie osłabła. Niemniej, do niedawna każda próba ingerencji Turcji w sprawy arabskie, zwłaszcza w konflikt arabsko-izraelski, była traktowana przez Arabów co najmniej podejrzliwie. Zmiana nastąpiła dopiero w 2002 r., gdy władzę w Turcji przejęła konserwatywna Partia Sprawiedliwości i Rozwoju (AKP), próbująca połączyć elementy sekularyzmu oraz wolnego rynku z podstawowymi zasadami islamu. Od tego momentu tureckie władze zaczęły poprawiać pozycję Turcji w świecie arabskim, co było wynikiem przede wszystkim konsekwentnie realizowanej koncepcji polityki zagranicznej tzw. strategicznej głębi. Dyplomatyczne zaangażowanie w sprawy świata arabskiego miało jednak swoją cenę. Jak się wkrótce okazało, zmiany polityczne w państwach arabskich po 2010 r. stały się największym wyzwaniem dla polityki Turcji w regionach Bliskiego Wschodu oraz Afryki Północnej.

Celem niniejszego artykułu jest analiza wpływu procesu zmian w państwach arabskich po 2010 r. na politykę zagraniczną Turcji. By móc tego dokonać, konieczne jest znalezienie odpowiedzi na dwa podstawowe pytania badawcze. W jaki sposób i w jakim stopniu tak zwana arabska wiosna wpłynęła na zmiany w polityce zagranicznej Turcji? Jak Turcja stara się lub może wykorzystać zmiany w świecie arabskim z korzyścią dla własnych interesów politycznych? By odpowiedzieć na powyższe pytania należy porównać podstawowe założenia polityki zagranicznej Turcji w skali regionalnej przed i po 2010 r. Pomocna będzie także analiza działań podejmowanych przez tureckie władze w odniesieniu do poszczególnych państw Bliskiego Wschodu i Afryki Północnej.

1 Szerzej na temat złożonych relacji pomiędzy Turkami a Arabami w ramach Imperium Osmańskiego: J. Hathaway, Arabowie pod panowaniem Osmanów 1518-1800, Warszawa 2012; S. J. Shaw, E. K. Shaw, Historia Imperium Osmańskiego i Republiki Tureckiej, t. 2: 1808-1975, Warszawa 2012; E. Zürcher, Turcja. Od sultanatu do wspótczesności, Kraków 2013. 
Dodatkowe pytanie badawcze dotyczy oceny skuteczności polityki zagranicznej Turcji w obliczu gwałtownej zmiany jej obiektywnych uwarunkowań zewnętrznych. W opinii Justyny Zając oraz Ryszarda Zięby, do grupy uwarunkowań zewnętrznych polityki zagranicznej należy zaliczyć: 1) trendy ewolucji najbliższego danemu państwu środowiska międzynarodowego; 2) pozycję państwa w systemie stosunków i ról międzynarodowych oraz 3) strukturę i zasięg umownych powiązań międzynarodowych państwa oraz obowiązujące prawo międzynarodowe ${ }^{2}$. Na podstawie analizy drugiego z wymienionych uwarunkowań można zatem pokusić się o ocenę obecnej polityki zagranicznej Turcji w regionie.

Podstawę źródłową artykułu stanowią wypowiedzi czołowych polityków tureckich oraz opinie badaczy przedmiotu (wybrane artykuły naukowe, monografie, raporty). W tym kontekście należy zwrócić uwagę na brak oficjalnych dokumentów wydanych przez władze tureckie w odniesieniu do procesu zmian w państwach arabskich po 2010 r., który zmusza badacza do poszukiwań oraz analizy wielu rozproszonych źródeł. Szczegółowej analizie zostaną zatem poddane przede wszystkim podstawowe założenia polityki zagranicznej Turcji przed 2010 rokiem oraz ich późniejsza, ewentualna modyfikacja w obliczu zmian politycznych w świecie arabskim.

Wyjaśnienia wymaga stosowane w tekście określenie proces zmian politycznych w państwach arabskich. Pojęcie to ma charakter autorski i stanowi próbę odejścia od szeroko stosowanych w literaturze przedmiotu, nieprecyzyjnych określeń o charakterze opisowym lub symbolicznym, których zdefiniowanie w teorii nauk politycznych jest nawet niemożliwe. Co więcej, żadne z nich nie ma charakteru uniwersalnego, który pozwalałby stosować je w odniesieniu do wydarzeń we wszystkich państwach arabskich. Do tej grupy należy zaliczyć przede wszystkim najpopularniejsze pojęcia takie jak arabska wiosna (ang. the Arab Spring) ${ }^{3}$, arabskie przebudzenie (ang. the Arab Awakening $)^{4}$, rewolucja arabska (ang. the Arab Revolution) ${ }^{5}$, arabskie powstanie (ang. the Arab Uprising) ${ }^{6}$, e-rewolucję czy też islamskie przebudzenie (ang. the Islamic Awakening) ${ }^{7}$.

${ }^{2}$ R. Zięba, Uwarunkowania polityki zagranicznej państwa, w: Wstęp do teorii polityki zagranicznej państwa, red. R. Zięba, Toruń 2004, s. 30-33.

3 Arab Spring Dreams: The Next Generation Speaks Out For Freedom and Justice From North Africa to Iran, eds. N. Weddady, S. Ahmari, New York 2012; H. Dabashi, The Arab Spring: the End of Postcolonialism, London 2012; J. R. Bradley, After the Arab Spring: How Islamists Hijacked the Middle East Revolts, Basingstoke 2012; L. Noueihed, A. Warren, The Battle for the Arab Spring: Revolution, Counter-revolution and the Making of a New Era, London 2012; J. West, Karama! Journeys Through the Arab Spring: Exhilarating Encounters With Those Who Sparked A Revolution, London 2011; S. Abudayeh, Poczqtek wiosny arabskiej w Tunezji, Egipcie, Jemenie, Libii i Bahrajnie, w: Bliski Wschód coraz blizej, red. J. Danecki, S. Sulowski, Warszawa 2011.

${ }^{4}$ S. Bar, Rewolucja na Bliskim Wschodzie: przebudzenie arabskie, w: Bliski Wschód coraz blizej, op. cit.; T. Ramadan, The Arab Awakening: Islam and the New Middle East, London 2012.

J. P. Filiu, The Arab Revolution: Ten Lessons From the Democratic Uprising, London 2011; The New Arab Revolt: What Happened, What It Means, and What Comes Next, New York 2011.

6 J. L. Gelvin, The Arab Uprisings: What Everyone Needs to Know, Oxford 2012; K. Dalacoura, The Arab Uprisings Two Years On: Ideology, Sectarianism and the Changing Balance of Power in the Middle East, „Insight Turkey” 2013, Vol. 15, No. 1.

7 Krytyczna analiza pojęć stosowanych w odniesieniu do procesu zmian w państwach arabskich po 2010 r. zob.: P. Osiewicz, Zmiany społeczno-polityczne w państwach arabskich po 2010 roku: 


\section{PODSTAWY POLITYKI ZAGRANICZNEJ TURCJI ZA RZĄDÓW PARTII SPRAWIEDLIWOŚCI I ROZWOJU (AKP): IMPLIKACJE DLA REGIONU BLISKIEGO WSCHODU}

Do 2002 r. relacje Turcji z innymi państwami bliskowschodnimi uznać można co najmniej za złożone ${ }^{8}$. Turcja rywalizowała z Syrią, obawiała się polityki prowadzonej przez Irak za rządów Saddama Husajna i nie ufała władzom irańskim, obawiając się kolejnych prób „eksportu” ideałów rewolucji islamskiej. Sytuację dodatkowo komplikował fakt bliskich relacji łączących Turcję z Izraelem. Współpraca z Izraelczykami od wielu lat osłabiała prestiż i wiarygodność Turków w świecie muzułmańskim, zwłaszcza w oczach Arabów. Próby normalizacji stosunków z sąsiadami na ogół kończyły się niepowodzeniem bądź jedynie krótkotrwałą poprawą wzajemnych stosunków. Sytuacja zmieniła się dopiero wraz z dojściem do władzy Partii Sprawiedliwości i Rozwoju.

Podstawowe kierunki i założenia polityki zagranicznej Turcji w okresie rządów partii AKP zostały sformułowane przez obecnego ministra spraw zagranicznych Ahmeta Davutoğlu. Na długo przed tym nim stanął na czele tureckiej dyplomacji, Davutoğlu opublikował pracę naukową zatytułowaną Strategiczna głębia (tur. Stratejik derinlik) ${ }^{9}$. Jego koncepcja polityki zagranicznej, realizowana w praktyce od końca 2002 r., zakładała przede wszystkim normalizację stosunków ze wszystkimi państwami sąsiednimi. Od powodzenia tego procesu Ahmet Davutoğlu uzależniał możliwość intensyfikacji stosunków politycznych i gospodarczych Turcji z pozostałymi państwami europejskimi, bliskowschodnimi czy też państwami Azji Centralnej. Tym samym wyeliminowanie problemów w relacjach z sąsiadami miało zagwarantować Turcji strategiczną głębię ${ }^{10}$.

Praktyczny wymiar koncepcji Davutoğlu stanowiły, między innymi, próba uregulowania kwestii cypryjskiej oraz normalizacja stosunków dwustronnych odpowiednio z Iranem, Armenią, Syrią oraz Irakiem. W kontekście zmian polityczno-społecznych w regionie bliskowschodnim po 2010 r. na szczególną uwagę zasługują wcześniejsze procesy zbliżenia stron w ramach stosunków turecko-irańskich oraz turecko-syryjskich. W obu przypadkach dyplomacja turecka wyraźnie zaakcentowała swą niezależność w relacjach ze Stanami Zjednoczonymi. Bez wątpienia administracja amerykańska nie była zadowolona z intensyfikacji współpracy między Turcją a Syrią i Iranem, które

tyczna analiza stosowanych pojęć, w: Oblicza Arabskiej Wiosny, red. R. Fiedler, P. Osiewicz (w przygotowaniu).

8 Więcej na temat bliskowschodniej polityki Turcji przed i tuż po dojściu AKP do władzy: L. G. Martin, Turkey's Middle East Foreign Policy, w: The Future of Turkish Foreign Policy, eds. L. G. Martin, D. Keridis, Cambridge 2004.

9 A. Davutoğlu, Stratejik derinlik. Türkiye'nin uluslararası konumu, Istanbul 2012.

${ }_{10}$ Co ciekawe, badacze irańscy stosują pojęcie szyickiej strategicznej głębi. U podstaw ich koncepcji tkwi założenie o powiązaniu bezpieczeństwa narodowego Iranu z sytuacją polityczną w Iraku, Syrii i Libanie. Właśnie koniecznością realizacji koncepcji szyickiej strategicznej thumaczy się konsekwencję, z jaką władze Iranu wspierają prezydenta Syrii Baszara al-Assada. Ewentualna porażka obecnego prezydenta w tym arabskim państwie doprowadziłaby nie tylko do utraty wpływów i kluczowego sojusznika w regionie, ale wręcz zagroziłaby bezpieczeństwu i ciagłości ustrojowej w Iranie. Szerzej o wzroście siły szyitów w regionie: Y. Hazran, The Rise of Politicized Shi 'ite Religiosity and theTerritorial State in Iraq and Lebanon, „The Middle East Journal” 2010, Vol. 64, No. 4. 
Waszyngton postrzegał i nadal postrzega jako państwa prowadzące politykę antyamerykańską. Lider opozycyjnej Republikańskiej Partii Ludowej (CHP), Kemal Kılıçdaroğlu, wprost zarzucał nawet rządowi AKP, że realizowana koncepcja polityki zagranicznej nie tylko nie przyczyniła się do poprawy relacji z państwami sąsiednimi, lecz wręcz je pogorszyła, a ponadto negatywnie wpłynęła na stosunki transatlantyckie i zagroziła bliższej współpracy z UE i Izraelem ${ }^{11}$.

Szczególnie złożony był proces zbliżenia stron między Turcją a Syrią. Do momentu przejęcia władzy przez AKP, relacje były napięte, a w 1998 r. groziły nawet wybuchem konfliktu zbrojnego. Polityka strategicznej głębi przyczyniła się do rozpoczęcia współpracy na linii Ankara-Damaszek, choć należy wyraźnie podkreślić, że, wbrew założeniom koncepcji Davutoğlu, nie udało się wyeliminować przyczyn wcześniejszych napięć. Przede wszystkim kwestii poszanowania praw Turkmenów, mieszkających w Syrii, oraz powiązań pomiędzy tureckimi i syryjskimi Kurdami, zwłaszcza w kontekście wsparcia udzielanego członkom Partii Pracujących Kurdystanu (PKK) ${ }^{12}$. Niemniej, władzom Turcji i Syrii udało się doprowadzić do zniesienia wiz, ożywienia wymiany handlowej oraz doprowadzić do kilku spotkań na najwyższym szczeblu. W ich trakcie premier Turcji Recep Tayyip Erdoğan miał się zwracać do prezydenta Sy-

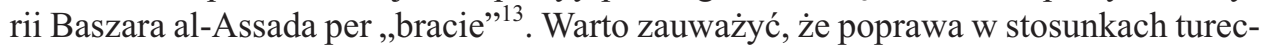
ko-syryjskich umożliwiła realizację kolejnego kroku - normalizację stosunków Turcji z Iranem ${ }^{14}$. Władze Iranu, dla których Syria jest czołowym sojusznikiem w regionie, zaczęły przychylniej traktować Turcję zgodnie z zasadą ,przyjaciele moich przyjaciół są moimi przyjaciółmi”.

Na początku 2011 r. Ahmet Davutoğlu, zapytany o główne przyczyny konfliktów i napięć w regionie Bliskiego Wschodu, wskazał na konflikt arabsko-izraelski oraz brak efektywnej współpracy. Podkreślił, iż Turcja była aktywnym promotorem współpracy regionalnej, szczególnie $\mathrm{w}$ ciągu ostatnich dziesięciu lat ${ }^{15}$. Jednocześnie przedstawił turecką koncepcję rozwiązania problemów regionalnych: „Wierzymy, że współpraca oparta na dialogu politycznym, ekonomicznej współzależności oraz kulturowym zrozumieniu jest najbardziej efektywnym środkiem służącym do zminimalizowania ryzyka konfliktu oraz promującym pokój, bezpieczeństwo i dobrobyt" ${ }^{\prime 16}$.

Jednakże koncepcja autorstwa Ahmeta Davutoğlu wykraczała daleko poza najbliższe otoczenie geopolityczne. Politykę zagraniczną Turcji za rządów AKP można określić mianem neoosmańskiej, choć jednocześnie należy wyraźnie podkreślić, iż Turcja próbuje uzyskać wpływy w regionie, a nie je odzyskać. Tym samym stosowanie terminu neoosmanizm można uznać za nadużycie. Imperium Osmańskie, które w przeszłości kontrolowało znaczne obszary Bliskiego Wschodu i Afryki Północnej, było państwem

11 Interview with Kemal Kıllçdaroğlu, „Turkish Policy Quarterly”2010/11, Vol. 9, No. 4, s. 27.

12 M. E. Y1lmaz, The Syrian uprising and the future of Turkish-Syrian relations, „Turkish Review" 2011, Vol. 1, No. 5, s. 50.

13 Ibidem, s. 55.

14 Szerzej: P. Osiewicz, Stosunki irańsko-tureckie na poczatku XXI wieku: implikacje dla regionu Bliskiego Wschodu, „Przegląd Strategiczny” 2011, nr 1.

15 Jako przykład można wskazać podjętą przez Turcję próbę mediacji między Syrią i Izraelem.

${ }^{16}$ C. Aksoy, A Vision Without Borders. Interview with Turkish Foreign Affairs Minister Ahmet Davutoğlu, „The Turkish Perspective” 2011, No. 3, s. 44. 
wielonarodowym, z kolei Turcja jest państwem narodowym. Nie można wprost założyć, iż Turcja jest sukcesorką Imperium Osmańskiego. Wyjątek stanowiły postanowienia traktatu pokojowego zawartego w Lozannie w 1923 r. Niemniej, termin neoosmanizm przyjął się i zdążył już upowszechnić w literaturze przedmiotu dla opisania tak zwanej wielkiej strategii Turcji na Bliskim Wschodzie. W tym kontekście nowe znaczenie uzyskał także termin panturkizm ${ }^{17}$.

Zdaniem Ofry Bengio, w polityce zagranicznej Turcji po 2002 r. można wskazać następujące założenia dotyczące polityki wobec regionu Bliskiego Wschodu:

- wypełnianie roli państwa osiowego w regionie (neoosmanizm);

- multilateralizm;

- eliminacja problemów z państwami w regionie, zwłaszcza sąsiednimi ${ }^{18}$;

- pełnienie funkcji mediatora w sporach i konfliktach regionalnych;

- prowadzenie polityki równowagi między kierunkiem europejskim a bliskowschodnim;

- wypełnianie roli wzoru demokratycznego państwa muzułmańskiego dla państw arabskich, będącego zarazem przeciwwagą dla modelu irańskiego ${ }^{19}$.

Powyższe założenia są zarazem głównymi punktami strategii Ahmeta Davutoğlu. Można posłużyć się nimi jako czynnikami pomocnymi podczas analizy porównawczej polityki zagranicznej przed i po 2010 r. Po ponad dziesięciu latach rządów Partii Sprawiedliwości i Rozwoju, istotnych zmianach politycznych w regionie oraz doświadczeniach ponad dwóch lat przemian politycznych w państwach arabskich pojawia się jednak pytanie dotyczące nie tylko ich aktualności, ale także skuteczności.

\section{POLITYKA ZAGRANICZNA TURCJI A PROCES PRZEMIAN W PAŃSTWACH ARABSKICH: REAKCJE NA ZMIANĘ OBIEKTYWNYCH UWARUNKOWAŃ ZEWNĘTRZNYCH}

Bez wattpienia gwałtowne zmiany w państwach arabskich stanowiły zaskoczenie dla władz Turcji. Przedtem Ankara, przynajmniej oficjalnie, nie starała się i nie zamierzała ingerować w sprawy wewnętrzne poszczególnych państw arabskich, ani tym bardziej wpływać na działalność organizacji opozycyjnych. Tym można tłumaczyć relatywnie niski poziom przygotowania Turcji do stawienia czoła zmianom politycznym w Afryce Północnej i na Bliskim Wschodzie. Wraz z rozwojem wydarzeń zarówno premier Erdoğan, jak i minister Davutoğlu byli zmuszeni zmodyfikować politykę zagraniczną Turcji, gdyż nie przystawała już ona do nowych okoliczności. Szczególnym testem polityki strategicznej głębi, a zarazem najbardziej spektakularnym przykładem jej niepowodzenia, stał się konflikt wewnętrzny w Syrii.

Wraz z początkiem antyrządowych protestów w Syrii zaczęły komplikować się relacje turecko-syryjskie, choć na początku 2011 r. jeszcze nic nie wskazywało, by mogło

${ }_{17}$ Bardzo ciekawą publikację na ten temat przedstawił Hugh Pope. Zob.: H. Pope, Sons of the Conquerors: The Rise of the Turkic World, New York 2005.

18 W tym przypadku podstawowe założenie dotyczyło normalizacji stosunków z Syrią i Iranem.

19 O. Bengio, Altercating Interests and Orientations between Israel and Turkey: A View from Israel, „Insight Turkey” 2009, Vol. 11, No. 2, s. 44. 
dojść do tak znacznego ich pogorszenia. Jednakże linia polityczna przyjęta przez Baszara al-Assada oraz jego przyzwolenie na użycie siły w stosunku do ludności cywilnej sprawiły, że Turcja w krótkim czasie stała się jednym z najostrzejszych krytyków syryjskiego reżimu. Początkowo władze w Ankarze próbowały wpłynąć na Baszara al-Assada, by zagwarantował pokój wewnętrzny, czego najlepszy przykład stanowi wizyta Ahmeta Davutoğlu w Damaszku w sierpniu 2011 r. Wkrótce okazało się jednak jak kruche były podstawy turecko-syryjskiej współpracy. Apele władz Turcji nie spotkały się z pozytywną reakcją ze strony Syrii, co w Ankarze zostało odebrane jako afront. Co więcej, władze syryjskie zaczęły oskarżać Turcję o ingerencję w sprawy wewnętrzne oraz wspieranie grup opozycyjnych, a nawet o ich dozbrajanie. W rezultacie władze Turcji jednoznacznie potępiły działania podejmowane przez Syrię i wezwały Baszara al-Assada do ustąpienia. Jednocześnie przyjęły tysiące uchodźców oraz zezwoliły na spotkania liderów syryjskich ugrupowań opozycyjnych na swoim terytorium. W październiku 2012 r. oba państwa znalazły się nawet niebezpiecznie blisko wybuchu konfliktu zbrojnego po tym jak oddziały wierne Assadowi miały ostrzelać jedną z przygranicznych miejscowości tureckich ${ }^{20}$. I choć ostateczny wynik konfliktu wewnętrznego w Syrii wciąż stanowi wielką niewiadomą, pewne jest, że turecka polityka eliminacji problemów z sąsiadami nie sprawdziła się w przypadku Syrii.

Nowy antagonizm w relacjach pomiędzy Turcją i Syrią musiał wpłynąć z kolei negatywnie na stosunki turecko-irańskie. Jednoznaczne poparcie udzielone syryjskiej opozycji przez rząd Turcji doprowadziło do napięć z Iranem, który od lat wspiera reżim Assadów $^{21}$. Z perspektywy irańskiej, utrzymanie Syrii jako sojusznika, rządzonego przez al-Assada, stanowi nie tylko jedną z gwarancji bezpieczeństwa zewnętrznego, ale także gwarancję przetrwania teokratycznego reżimu w Iranie.

Tureckie władze w sposób jednoznaczny udzieliły również poparcia ruchom opozycyjnym w Libii, Tunezji i Egipcie. Terytoria wymienionych państw stanowiły w przeszłości części terytorium Imperium Osmańskiego, czym należy tłumaczyć żywotne zainteresowanie Turcji sytuacją w Afryce Północnej. W przypadku Egiptu należy jednak zwrócić uwagę na pewien paradoks. Wspieranie przemian w Egipcie stoi w sprzeczności z założeniami polityki zagranicznej Turcji, ponieważ silny, stabilny Egipt będzie stanowił istotną konkurencję dla wpływów tureckich w innych państwach arabskich. Z pewnością będzie też aspirował do roli regionalnego mocarstwa. Niemniej, póki co dla obu stron współpraca jest o wiele korzystniejsza aniżeli rywalizacja o wpływy w świecie muzułmańskim, zwłaszcza arabskim. Na uwagę zasługuje także entuzjazm, z jakim Egipcjanie witali szefa tureckiego rządu. Wydarzenie, które jeszcze dziesięć lat temu było niewyobrażalne, zwłaszcza ze względu na skomplikowaną historię, teraz stało się faktem. Tym samym Turcja odniosła sukces wizerunkowy, a premier Erdoğan stał się dla większości Egipcjan wzorem przywódcy, który potrafi łączyć w polityce wartości demokratyczne z podstawowymi zasadami islamu.

${ }^{20}$ M. Giglio, The Next Front? Rising Tensions on the Turkey-Syria border, „Newsweek”, 22.10.2012.

21 Szerzej: J. Goodarzi, Syria and Iran: Diplomatic Alliance and Power Politics in the Middle East, London 2006; A. Ehteshami, R. A. Hinnebusch, Syria and Iran: Middle powers in a penetrated regional system, London 1997. 
Znaczenie wzajemnej współpracy zostało podkreślone już przy okazji pierwszej wizyty premiera Erdoğana w Egipcie po odsunięciu od władzy prezydenta Mubaraka. W jej trakcie podpisana została umowa przewidująca utworzenie rady do spraw współpracy strategicznej ${ }^{22}$. Należy uznać, że w odróżnieniu od Syrii, polityka zagraniczna realizowana przez rząd AKP sprawdziła się, a nawet więcej - turecki rząd dobrze wykorzystał sprzyjające okoliczności, by umocnić swoją pozycję w oczach obywateli państwa, które potencjalnie wkrótce może zagrozić regionalnej pozycji Turcji. Ryzyko uda się oddalić, jeśli władzą w Egipcie będą dysponowali politycy wzorujący się na tureckim modelu rządów. Jeśli będą mogli przy tym liczyć na wsparcie ze strony władz w Ankarze, Turcji uda się zneutralizować i związać ze sobą najsilniejsze i najbardziej wpływowe, obok Arabii Saudyjskiej, państwo arabskie.

W przypadku Libii Turcja od samego początku zdecydowanie potępiała stosowanie siły przez reżim Kaddafiego w stosunku do ludności cywilnej. Podobnie jak to miało miejsce w przypadku Syrii, turecki rząd początkowo analizował rozwój sytuacji. Jednocześnie ostro sprzeciwiał się jakiejkolwiek interwencji. Tym samym Turcja stała się jednym z największych krytyków operacji prowadzonej przez francuskie siły powietrzne. Ankara zarzucała rządowi Francji, że ten próbuje wykorzystać wewnętrzną rywalizację w Libii do rozszerzenia francuskiej strefy wpływów w Afryce Północnej ${ }^{23}$.

Turcja próbowała także prowadzić mediację pomiędzy siłami Kaddafiego a rebeliantami. Jednym z jej efektów była turecka propozycja pokojowa, która zakładała wycofanie wojsk wiernych M. Kaddafiemu z miast opanowanych przez rebeliantów oraz przeprowadzenie demokratycznych reform. Zasadniczą przeszkodę w procesie mediacji stanowił jednak fakt, iż libijska opozycja zdecydowanie odrzucała każdy scenariusz, który zakładał pozostanie M. Kaddafiego przy władzy, natomiast libijski przywódca nie dopuszczał nawet myśli o ustąieniu ${ }^{24}$. Dopiero później, latem 2011 r., gdy M. Kaddafi podjął zdecydowaną ofensywę wojskową, Turcja próbowała wywierać presję na rząd w Trypolisie i jednocześnie udzieliła wsparcia siłom opozycyjnym. Już na samym początku tureckie władze przekazały libijskim rebeliantom 200 milionów USD, a minister spraw zagranicznych Ahmet Davutoğlu odwiedził Bengazi na początku lipca $2011 \mathrm{r}^{25}$ Takie działania były korzystne nie tylko dla rebeliantów, ale także dla wizerunku Turcji, która w ten sposób zyskiwała uznanie w świecie arabskim, w większości zdecydowanie potępiającym brutalne represje stosowane przez reżim libijski. Można jednak zaryzykować stwierdzenie, iż turecki rząd poparł rebeliantów w momencie, gdy ich zwycięstwo wydawało się być przesądzone. Tym samym Turcja próbowała zagwarantować sobie wpływy i dobre relacje w Libii po przejęciu władzy przez opozycję. Równocześnie starała się przekonać społeczność międzynarodową, iż jest gotowa podejmować zdecydowane, konkretne działania w imię ochrony praw człowieka.

22 K. E. Uchehara, Erdoğan's Mideast and African Tour: Putting Turkey on the Map, „Turkish Review" 2011, No. 6.

${ }^{23}$ I. Traynor, Turkey and France clash over Libya air campaign, http://www.guardian.co.uk/ world/2011/mar/24/turkey-france-clash-libya-campaign (27.03.2013).

${ }^{24}$ C. McGreal, H. Sherwood, S. Milne, Libyan minister to take Turkish peace plan to Gaddafi, http://www.guardian.co.uk/world/2011/apr/07/libya-minister-turkish-peace-plan-gaddafi (27.03.2013).

${ }_{25}$ Turkey recognizes Libya rebels, http://www.aljazeera.com/news/africa/2011/07/201173145 538817561.html (27.03.2013). 
W tym kontekście należy zwrócić uwagę na podwójne standardy stosowane przez Turcję. Choć Ankara zdecydowanie potępiała władze Libii czy Syrii za prześladowania ludności cywilnej, jednocześnie nie interweniowała podczas przypadków łamania praw człowieka podczas protestów w Bahrajnie czy Arabii Saudyjskiej.

Wydarzenia $\mathrm{z}$ okresu przemian politycznych w państwach arabskich ujawniły również istotną wadę realizowanej przez rząd AKP koncepcji polityki zagranicznej. Było nią oparcie wzajemnych stosunków przede wszystkim na osobistych relacjach pomiędzy przywódcami. Liderzy mieli stanowić przykład dla społeczeństwa, stąd niekiedy nawet przesadnie podkreślano rolę przyjacielskich relacji między Erdoğanem a Assadem. Podobnie było w przypadku Hosni Mubaraka, choć w tym przypadku osobiste relacje miały wymiar bardziej pragmatyczny.

Należy także zauważyć, iż na długo przed pierwszymi wydarzeniami w ramach procesu tak zwanej arabskiej wiosny, Turcja postawiła na budowę dobrych relacji oraz prestiż w świecie arabskim kosztem dobrych relacji z Izraelem. Do 2009 r. Turcję i Izrael łączyły dobre stosunki, które były korzystne także z punktu widzenia bliskowschodniej polityki Stanów Zjednoczonych ${ }^{26}$. Przejawami radykalnej zmiany polityki wobec Izraela były, między innymi, zdecydowane potępienie Izraela za przeprowadzenie operacji Płynny Ołów w Strefie Gazy w styczniu 2009 r. oraz reakcje władz Turcji po incydencie Flotylli Wolności, z udziałem tureckiego statku „Mavi Marmara” w maju 2010 r. ${ }^{27}$ W styczniu 2009 r. premier Turcji, na znak protestu przeciwko izraelskiej operacji zbrojnej w Gazie, ostentacyjnie opuścił salę obrad podczas szczytu w Davos, gdzie miał wziąć udział w dyskusji panelowej wraz z premierem Izraela Szimonem Pere$\mathrm{sem}^{28}$. Akt ten został bardzo negatywnie odebrany przez zgromadzonych na sali, ale jednocześnie przysporzył Erdoğanowi wielu nowych zwolenników nie tylko w Turcji, lecz przede wszystkim w świecie arabskim. Zaostrzenie polityki wobec Izraela przyniosło oczekiwane przez tureckie władze rezultaty podczas procesu przemian w państwach arabskich. Turcja, przedstawiana przedtem w świecie arabskim jako państwo, które budowanie wspólnoty muzułmańskiej poświęciło na rzecz sojuszu ze Stanami Zjednoczonymi, członkostwa w NATO czy też współpracy z Izraelem, zaczęła być postrzegana jako przykład udanego połączenia wartości demokratycznych z podstawowymi wartościami islamu. Zarówno w Tunezji, jak i Egipcie szczegółowo analizowano tak zwany model turecki, stanowiący szansę na szybką modernizację przy jednoczesnym zachowaniu muzułmańskiego charakteru państwa. Demonstranci w Egipcie protestowali ze zdjęciami tureckiego premiera Recepa Tayyipa Erdoğana w dłoniach, co stało się znaczącym symbolem zmiany w podejściu Arabów względem Turków. Do tamtej pory Turcy byli kojarzeni przede wszystkim z dominacją i podporządkowaniem

\footnotetext{
${ }^{26}$ Szerzej na temat stosunków turecko-izraelskich przed 2010 rokiem: O. Bengio, The Turkish-Israeli Relationship: Changing Ties of Middle Eastern Outsiders, New York 2010.

27 Szerzej o przebiegu oraz konsekwencjach incydentu związanego z zajęciem tureckiego statku „Mavi Marmara": Midnight on the Mavi Marmara: The Attack on the Gaza Freedom Flotilla and How It Changed the Course of the Israel/Palestine Conflict, ed. M. Bayoumi, Chicago 2010; Drawing a Line in the Sea: The Gaza Flotilla Incident and the Israeli-Palestinian Conflict, ed. T. E. Copeland, New York 2011.

28 Szerzej: G. Bacık, Turkish-Israeli Relations After Davos: A View from Turkey, „Insight Turkey" 2009, Vol. 11, No. 2.
} 
sobie Arabów w ramach Imperium Osmańskiego. Tymczasem w ramach procesu zmian politycznych w państwach arabskich po $2010 \mathrm{r}$. Turcja stała się nagle atrakcyjnym wzorem, synonimem sukcesu gospodarczego i politycznego ${ }^{29}$. Przykładowo, model turecki był o wiele bardziej interesujący aniżeli „model irański” nawet, a może nawet przede wszystkim dla egipskiego Bractwa Muzułmańskiego, którego aktywność w pierwszym okresie przemian była traktowana podejrzliwie przez państwa Zachodu. Jeszcze na początku 2011 r., tuż po odsunięciu od władzy Hosni Mubaraka, powszechna była obawa, iż przejęcie władzy przez Bractwo doprowadzi do radykalizacji norm społecznych oraz poważnego ograniczenia relacji z Zachodem ${ }^{30}$.

Jak udowodniono, we wszystkich wspomnianych przypadkach tureckie władze nie reagowały od razu, lecz ich działania stanowiły odpowiedź na zmianę uwarunkowań zewnętrznych. Takie postępowanie można zinterpretować dwojako. Albo jako przejaw pragmatyzmu, albo też jako przejaw zachowawczej polityki i braku przygotowania na zmianę. Niemniej, według Ziyi Önişa, etapy w odpowiedzi Turcji na procesy zmian w państwach arabskich można scharakteryzować w następujący sposób:

- ostrożny unilateralizm;

- niechętny udział;

- jednostronny proaktywizm;

- powrót od ostrożnej polityki ${ }^{31}$.

Na podstawie wspominanych argumentów, można przedstawić główne cele polityki zagranicznej na Bliskim Wschodzie po 2010 r. i porównać je z celami sprzed 2010 r., scharakteryzowanymi przez Ofrę Bengio. $Z$ wykazu celów z pewnością można usunąc dwa punkty: eliminację problemów z państwami w regionie (niepowodzenie, zwłaszcza w przypadku Syrii) oraz niemożność pełnienia funkcji państwa mediatora w sporach i konfliktach regionalnych (Syria-Izrael, nieudane próby pośrednictwa między Iranem a państwami Zachodu w sprawie irańskiego programu atomowego) $)^{32}$. Na początku 2013 r. lista celów regionalnej polityki zagranicznej Turcji obejmuje zatem:

- wypełnianie roli państwa osiowego w regionie (neoosmanizm);

- multilateralizm;

- prowadzenie polityki równowagi pomiędzy kierunkiem europejskim a bliskowschodnim;

- wypełnianie roli wzoru demokratycznego państwa muzułmańskiego dla państw arabskich, będącego zarazem przeciwwagą dla modelu irańskiego.

29 Szerzej: R. Abou-el-Fadl, Arab Perceptions of Contemporary Turkish Foreign Policy: Cautious Engagement and the Question of Independence, w: Another Empire? A Decade of Turkey's Foreign Policy Under the Justice and Development Party, eds. K. Öktem, A. Kadıoğlu, M. Karlı, Istanbul 2012.

${ }_{30}$ C. Dickey, B. Dehghanpisheh, Among the Believers: The Muslim Brotherhood stands up in Egypt, „Newsweek”, 14.02.2011.

31 Z. Öniş, Turkey and the Arab Spring: Between Ethics and Self-interest, „Insight Turkey” 2012, Vol. 14, No. 3, s. 51.

32 Dodatkowe argumenty niepowodzenia koncepcji eliminacji problemów z sąsiadami stanowią wciąż nieuregulowana kwestia cypryjska oraz polityczna rywalizacja z Armenią. 


\section{PAŃSTWA ARABSKIE A TURECKI MODEL RZĄDÓW: SZANSA NA POSZERZENIE WPLYWÓW TURCJI W REGIONIE?}

Jak wcześniej wspomniano, promocja tureckiego modelu ustrojowego stanowiła i nadal stanowi istotny element polityki zagranicznej Turcji. Rządy Partii Sprawiedliwości i Rozwoju w Turcji stanowią przykład udanej syntezy elementów demokracji liberalnej i gospodarki wolnorynkowej z podstawowymi zasadami islamu. Przeprowadzone zmiany konstytucyjne oraz liczne reformy złagodziły stricte sekularny i zlaicyzowany system, który obowiązywał w Turcji na mocy Konstytucji z 1982 r. Co więcej, dzięki polityce AKP, Turcja z państwa peryferyjnego stała się jednym z głównych graczy w regionie bliskowschodnim, a jej aspiracje sięgają nawet dalej - do Afryki, Azji Środkowej, Azji Południowo-Wschodniej, a nawet Ameryki Łacińskiej. Jednocześnie turecki rząd wciąż utrzymuje dobre kontakty z Zachodem i prowadzi skuteczną politykę równowagi. Gdyby państwa arabskie wzorowały się na Turcji, mógłby to być kolejny argument na rzecz rozszerzenia tureckich wpływów w świecie arabskim. Turecki model rządów stałby się wówczas jednym z elementów miękkiej siły i przykładem korzystnych, z punktu widzenia Turcji, interakcji z państwami arabskimi. Czy jednak sposób sprawowania rządów przez AKP jest rzeczywiście atrakcyjny dla państw arabskich, które do niedawna były rządzone w sposób autorytarny?

W 2011 r. we wszystkich państwach sąsiadujących z Turcją zostały przeprowadzone badania opinii publicznej dotyczące oceny roli Turcji w systemie międzynarodowym, regionie oraz jej polityki zagranicznej. Na pytanie czy Turcja mogłaby stać się wzorem dla innych państw bliskowschodnich, twierdząco odpowiedziało aż 75\% Irańczyków, 70\% Irakijczyków oraz 59\% Syryjczyków ${ }^{33}$. Zdecydowanie najwięcej ankietowanych wskazało także na Turcję jako państwo kojarzące się z pojęciem potęgi regionalnej (28\%). Drugi w kolejności Iran wybrało jedynie $12 \%$ respondentów ${ }^{34}$. Wyniki badań potwierdzily rosnący prestiż Turcji w regionie, choć należy wyraźnie zaznaczyć, że zostały przeprowadzone jeszcze przed udzieleniem wyraźnego poparcia syryjskiej opozycji przez turecki rząd. Od tego czasu nie zostały powtórzone, niemniej można przewidywać, że prawdopodobnie nie byłyby już tak korzystne dla strony tureckiej.

James M. Dorsey wskazuje, że tym, co decyduje o atrakcyjności modelu tureckiego jest fakt, iż umiarkowana partia islamska z powodzeniem rządzi sekularnym państwem, które dodatkowo odnosi znaczące sukcesy gospodarcze ${ }^{35}$. $Z$ kolei zdaniem Jurisa Pupcenoksa, zarówno Turcja, jak i Pakistan stanowią przykłady tak zwanej demokratycznej islamizacji. Oznacza to, iż w obu państwach partie odwołujące się do wartości islamu zdobyły władzę w sposób legalny, w ramach demokratycznych procesów wyborczych. Niemniej, o ile turecki rząd Partii Sprawiedliwości i Rozwoju stosuje łagodne środki i przeprowadza ewolucyjne zmiany systemowe, o tyle w Pakistanie zauważyć można elementy tak zwanej represywnej islamizacji. W opinii Pupcenoksa, z tego

33 S. Genç, Perception of Turkey's foreign policy among the elite of its neighbors, „Turkish Review" 2011, Vol. 1, No. 5, s. 29.

34 Ibidem, s. 28

35 J. M. Dorsey, Change in the Middle East Puts Turkey in the Eye of the Storm, „Turkish Policy Quarterly" 2010/11, Vol. 9, No. 4, s. 49. 
właśnie powodu model turecki jest o wiele bardziej atrakcyjny dla grup reformatorskich w poszczególnych państwach arabskich ${ }^{36}$. Należy dodać, iż w przeciwieństwie do Pakistanu, turecki model sprawowania rządów przeciwdziała, przynajmniej w teorii, antagonizowaniu różnych grup społecznych i etnicznych. Jako przykład może posłużyć próba poprawy relacji pomiędzy Turkami a tureckimi Kurdami. Próba, co trzeba wyraźnie podkreślić, w dużej mierze nieudana, ale wyznaczająca pewien trend. Rządowi AKP nie udało się całkowicie wyeliminować przemocy i wzajemnej niechęci, ale udało się obniżyć poczucie zagrożenia i poprawić poziom bezpieczeństwa wewnętrznego oraz zapewnić relatywnie lepszy byt mniejszości kurdyjskiej. Dlaczego jest to tak istotne? Ponieważ w zdecydowanej większości państw objętych tak zwaną arabską wiosną również istnieją silne podziały na tle etnicznym oraz wyznaniowym. Tym samym tureckie doświadczenia i rozwiązania systemowe mogą okazać się bardzo pomocne i użyteczne.

Jeden z przykładów korzystania z doświadczeń tureckiej partii AKP stanowi tunezyjska partia Harakat al-Nahda. Niemniej, jak zauważył Stefano Maria Torelli, „,chociaż al-Nahda oficjalnie przyznała, że w kilku kwestiach odniosła się do modelu tureckiego, to jednak nic, przynajmniej w skali krótkoterminowej, nie wskazuje na to, by model AKP został powielony w Tunezji, ${ }^{37}$. Taka obserwacja nie wyklucza jeszcze całkowicie szansy na zmiany polityczne w Tunezji według scenariusza tureckiego, jednakże jest ona mniej aniżeli bardziej prawdopodobna. Obecnie główna różnica zdań dotyczy podejścia do kwestii sekularyzmu oraz odmiennych kontekstów społeczno-kulturowych.

Tymczasem, jak utrzymuje Feriha Perekli, model turecki, nie ograniczany jedynie do okresu rząóow AKP w Turcji, jest atrakcyjny dla islamistów w Maroku. Przykład może stanowić przejęcie wielu rozwiązań tureckich przez rządzącą partię marokańską PJD (Parti de la Justice et du Développment), której nazwa jest identyczna z jej turecką odpowiedniczką AKP. Nawet logo PJD (zapalona lampka naftowa) nawiązuje do logo AKP (zapalona żarówka). Tym samym ,model turecki, łączący doświadczenia partii islamskich sprzed rządów AKP oraz doświadczenia okresu rządów AKP, stanowi źródło inspiracji dla marokańskiej PJD"38. Podobną partią polityczną, próbującą korzystać z doświadczeń tureckiej AKP, jest wpływowa egipska Partia Wolności i Sprawiedliwości (FJP) ${ }^{39}$. FJP, powiązana z Bractwem Muzułmańskim, ma już na swoim koncie zwycięstwo w wyborach parlamentarnych z przełomu 2011 i 2012 roku $^{40}$. Ponadto, no-

36 J. Pupcenoks, Democratic Islamization in Pakistan and Turkey: Lessons for the Post-Arab Spring Muslim World, ,The Middle East Journal” 2012, Vol. 66, No. 2, s. 273.

37 S. M. Torelli, The „AKP Model” and Tunisia's Al-Nahda: From Convergence to Competition, „Insight Turkey” 2012, Vol. 14, No. 3, s. 80.

${ }^{38}$ F. Perekli, The Applicability of the „Turkish Model” to Morocco, "Insight Turkey" 2012, Vol. 14, No. 3, s. 101.

39 H. Rane, An Alternative to the ,, Turkish Model” For the Emerging Arab Democracies, ,Insight Turkey" 2012, Vol. 14, No. 4, s. 50.

40 Przebieg procesu wyborczego został jednak uznany przez Najwyższy Trybunał Konstytucyjny Egiptu za niekonstytucyjny. Decyzja ta wywołała kolejną falę protestów społecznych. Na mocy dekretu prezydenta Morsiego z lipca 2012 r., także podważanego przez Trybunał, parlament ma funkcjonować aż do kolejnych wyborów, zaplanowanych pierwotnie na wiosnę 2013 r., przesuniętych jednak ostatecznie na jesień. 
wym prezydentem Egiptu wybrany został Mohamad Morsi - członek FJP, do czerwca 2012 r. pełniący funkcje przewodniczącego tej partii.

Jak już wcześniej wspomniano, Turcja zyskała uznanie w świecie arabskim po zmianie polityki względem Izraela. Ponadto, turecki rząd przestał podkreślać znaczenie silnych związków ze Stanami Zjednoczonymi oraz Unią Europejską. Owszem, kierunki europejski i transatlantycki nadal pozostają jednymi z ważniejszych w ramach polityki zagranicznej, niemniej już nie są najważniejszymi. Mounir Shafiq, jeszcze przed zmianami w państwach arabskich, wskazywał właśnie na zbyt prozachodnią orientację Turcji oraz jej dobre relacje z Izraelem jako główne przeszkody w upowszechnieniu się tureckiego modelu rządów ${ }^{41}$. Obecnie zauważyć należy swoistą politykę równowagi prowadzoną przez władze w Ankarze. Niemniej, to wciąż zbyt mało. Zdaniem Mohammeda Noureddine, obie strony powinny sięgnąć do teorii konstruktywizmu i rozpoczać zbliżenie stanowisk od zbliżenia pomiędzy elitami, zwłaszcza poprzez rozszerzenie wciąż niewielkiej współpracy w ramach nauki i kultury ${ }^{42}$.

Paradoksalnie, jedynym państwem arabskim, które przed 2011 r. chciało zacieśniać relacje z Turcją rządzoną przez AKP i korzystać z jej doświadczeń była Syria. Miało to jednak miejsce przed wybuchem konfliktu wewnętrznego oraz zdecydowanym poparciem udzielonym syryjskiej opozycji przez Turcję w 2011 r. Póki co, ostateczny wynik konfrontacji syryjskiej jest nieprzewidywalny. Jeśli jednak władzę przejmie opozycja, może, w ramach wdzięczności za otrzymaną pomoc, przeprowadzić reformy według tureckiego scenariusza i zacieśniać stosunki dwustronne.

Lista celów polityki zagranicznej Turcji w odniesieniu do polityki regionalnej po 2002 r., zaproponowana przez Ofrę Bengio, przy uwzględnieniu doświadczeń i wpływu procesu zmian politycznych w państwach arabskich na politykę zagraniczną Turcji po 2010 r., wymaga istotnej korekty. Za nieaktualne można uznać dwa z nich: eliminację problemów z państwami w regionie (niepowodzenie, zwłaszcza w przypadku Syrii) oraz niemożność pełnienia funkcji państwa mediatora w ramach konfliktu arabsko-izraelskiego, konfliktu wewnętrznego w Syrii oraz między Iranem i Zachodem w sprawie irańskiego programu atomowego.

Konflikt wewnętrzny w Syrii stał się bez wątpienia jednym z przykładów niepowodzenia polityki zagranicznej Turcji w jej wymiarze dotyczącym eliminacji problemów z państwami sąsiednimi. Jeśli dołączyć do tego brak normalizacji stosunków z Republiką Cypryjską czy też Armenią oraz narastanie wzajemnej nieufności w ramach stosunków irańsko-tureckich (radykalna różnica zdań w ocenie sytuacji w Syrii), można zgodzić się z coraz popularniejszym w kręgach dyplomatycznych stwierdzeniem, iż politykę zera problemów z sąsiadami (ang. zero problems with neighbours policy) zastąpiła polityka zera sąsiadów bez problemów (ang. zero neighbours without pro-

${ }^{41}$ M. Shafiq, Turkey's Justice and Development Party Through Arab Eyes, „Insight Turkey” 2009, Vol. 11, No. 1, s. 37.

${ }^{42}$ M. Noureddine, Arab-Turkish Cooperation in the New Era, „Insight Turkey” 2009, Vol. 11, No. 1, s. 50 . 
blems policy). Turcja odniesie sukces dyplomatyczny w Syrii tylko wówczas, gdy władzę przejmie w niej opozycja. Dopóki władzę będzie posiadał prezydent Baszar al-Assad, trudno wyobrazić sobie jakąkolwiek normalizację we wzajemnych stosunkach, zwłaszcza po tym jak Turcja zdecydowanie poparła siły antyrządowe.

Istotną wadę tureckiej polityki zagranicznej po 2002 r. stanowiło oparcie stosunków na bliskich, osobistych relacjach tureckich polityków z niektórymi autorytarnymi przywódcami państw arabskich. Najlepszy przykład stanowią stosunki turecko-syryjskie, a zwłaszcza osobiste relacje premiera Erdoğana oraz prezydenta Assada. Działania podejmowane przez syryjskiego lidera celem zdławienia protestów społecznych zmusiły Turcję do jednoznacznego potępienia arabskiego sojusznika. W przeciwnym razie premier Erdoğan pośrednio legitymizowałby użycie siły wobec ludności cywilnej przez Assada. Warto podkreślić, że Turcja stanęła przed trudnym wyborem - czy utrzymać dobre stosunki z Assadem i nie narazić się Iranowi, czy też lepiej potępić Assada, narazić się Irańczykom, ale jednocześnie zyskać uznanie ze strony państw arabskich na przykład, z regionu Zatoki Perskiej oraz Egiptu.

Paradoksalnie, wsparcie procesu przemian w Egipcie, może zagrozić regionalnym aspiracjom Turcji. Egipt stracił swą pozycję w regionie po podpisaniu układu pokojowego i nawiązaniu stosunków dyplomatycznych z Izraelem. Prezydent Mubarak był także krytykowany za zbyt bliską współpracę ze Stanami Zjednoczonymi. Obecny, ewentualny wzrost znaczenia regionalnego Egiptu oraz wzmocnienie egipskich wpływów w świecie arabskim będą niekorzystne dla regionalnych aspiracji Turcji. Niemniej, należy zauważyć, że Turcja odniosła sukces wizerunkowy w tym państwie. Powinna zatem stawiać na współpracę z Egiptem i próbować wspierać środowiska reformatorskie, próbujące przeprowadzać zmiany ustrojowe według wzoru tureckiego. Kluczowy pod tym względem będzie wynik wyborów parlamentarnych w Egipcie, przełożonych na jesień 2013 roku $^{43}$.

Pytanie dotyczące atrakcyjności tak zwanego modelu tureckiego dla państw arabskich pozostaje pytaniem otwartym. Chociaż można wskazać przykłady nawiązywania do politycznych doświadczeń Turcji w takich państwach jak Tunezja, Maroko czy Egipt, jest to jeszcze zbyt mało, by można mówić o politycznej miękkiej sile Turcji $\mathrm{w}$ regionie. Jednakże warto podkreślić, że proces zmian w wielu państwach arabskich, zwłaszcza w Egipcie, wciąż trwa. Tym samym wciąż możliwe jest, że państwa te podążą drogą Turcji i będą starały się pogodzić wartości islamu z systemem demokratycznym oraz gospodarką wolnorynkowa, przy jednoczesnym zagwarantowaniu sekularnego charakteru państwa oraz próbach łagodzenia skutków podziałów wewnętrznych na tle etnicznym czy też wyznaniowym.

\section{STRESZCZENIE}

Proces zmian w państwach arabskich, którego początek wyznaczyły protesty w Tunezji na przełomie 2010 i 2011 r., stanowił zaskoczenie nie tylko dla szeroko definiowanej społeczności

${ }^{43}$ Egypt court postpones verdict on parliamentary elections, http://english.ahram.org.eg/News Content/1/64/67608/Egypt/Politics-/Egypt-court-postpones-verdict-on-parliamentary-ele.aspx (4.04.2013). 
międzynarodowej, ale także dla najważniejszych graczy w regionach Bliskiego Wschodu oraz Afryki Północnej. Bez wątpienia do tej grupy zaliczyć należy Turcję. Celem niniejszego artykułu jest analiza wpływu procesu zmian w państwach arabskich po 2010 r. na politykę zagraniczną Turcji. Szczegółowej analizie zostały poddane przede wszystkim podstawowe założenia polityki zagranicznej Turcji przed 2010 r. oraz ich późniejsza, ewentualna modyfikacja w obliczu zmian politycznych w świecie arabskim. Na podstawie analizy, autor za nieaktualne uznał dwa z regionalnych celów polityki zagranicznej Turcji: eliminację problemów z państwami w regionie oraz niemożność pełnienia funkcji państwa mediatora w regionie. Konflikt wewnętrzny w Syrii stał się bez wątpienia jednym z przykładów niepowodzenia polityki zagranicznej Turcji. Istotną wadę tureckiej polityki zagranicznej po 2002 r. stanowiło oparcie stosunków na bliskich, osobistych relacjach tureckich polityków z niektórymi autorytarnymi przywódcami państw arabskich. Paradoksalnie, wsparcie procesu przemian w Egipcie, może zagrozić regionalnym aspiracjom Turcji. Pytanie dotyczące atrakcyjności tak zwanego modelu tureckiego dla państw arabskich pozostaje pytaniem otwartym. Chociaż można wskazać przykłady nawiązywania do politycznych doświadczeń Turcji w takich państwach jak Tunezja, Maroko czy Egipt, jest to jeszcze zbyt mało, by można mówić o politycznej miękkiej sile Turcji w regionie.

\title{
THE PROCESS OF CHANGES IN THE ARAB STATES AND ITS INFLUENCE ON THE TURKISH POLICY AFTER 2010
}

\begin{abstract}
The process of political changes in the Arab states, which began in Tunisia in 2010, came as a complete surprise not only to international community, but also to all key players in the Middle East and in North Africa. Undoubtedly, Turkey was one of them. The main aim of this article is to analyze influence of the process on the foreign policy of Turkey after 2010. In order to do that, the author analyzes fundamental objectives of the Turkish foreign policy before and after 2010 . He argues that two of them, namely zero problems with neighbors policy as well as a role of a mediator in the Middle East, are not valid anymore. Moreover, the internal conflict in Syria became a symbol of a failure of zero problems with neighbors policy. One of the weaknesses of the Turkish foreign policy was its dependence on personal relations between Turkish politicians and authoritarian leaders in the Arab states. Paradoxically, although Turkey supports changes in Egypt, this state can become its biggest regional rival in the nearest future. Last but not least, the author tries to find out whether so-called Turkish political model is attractive to the Arab states. He claims that although we can find some examples how Arab politicians follow the Turkish example in Tunisia, Morocco or Egypt, it is still not enough to assert that these states have already adopted the Turkish model.
\end{abstract}

